\title{
Gerenciamento de recursos hídricos no Brasil e no estado de São Paulo: um novo modelo de política pública
}

\author{
Jésus de Lisboa Gomes * \\ José Carlos Barbieri **
}

\begin{abstract}
Resumo
A água doce, um bem vital para vida dos seres vivos e um dos principais recursos para o desenvolvimento das nações, encontra-se escasso ou em estado de grande degradação em muitas regiões do mundo, inclusive no Brasil. 0 principal desafio é a gestão sustentável do suprimento e da demanda de água para que as atuais gerações supram as suas necessidades sem comprometer a possibilidade de que as futuras gerações também o façam. A gestão do suprimento implica implementar políticas de identificação e desenvolvimento de novas fontes de água e da demanda e a introdução de instrumentos que promovam a sua conservação e uso eficiente. No Brasil, a regulamentação desse assunto iniciou-se na década de 1930, fundamentando-se num modelo centralizado e sob forte influência do setor elétrico. Com a Constituição Federal de 1988, começou a ser criado um novo sistema de gestão, integrado, democrático e descentralizado, tendo a bacia hidrográfica como unidade de referência e gerenciamento. Este sistema combina a aplicação de diferentes mecanismos de regulação, contemplando instrumentos de comando e controle, econômicos e de educação ambiental. 0 planejamento é compartilhado entre o poder público, organizações da sociedade civil e usuários, integrando decisões sobre desenvolvimento, uso de água, saneamento e meio ambiente, envolvendo uma diversidade de agentes com objetivos contraditórios, fazendo com que os interesses de uns funcionem como reguladores dos interesses de outros. Neste trabalho analisa-se a implementação desse sistema no Brasil e no Estado de São Paulo, com vistas a discutir as suas características fundamentais, delinear as diferenças entre os dois modelos, destacar os principais problemas existentes e como esses problemas estão sendo tratados.
\end{abstract}

Palavras-chave: Recursos naturais, água doce, política pública, gerenciamento integrado, comitês de bacia.

\begin{abstract}
Freshwater, a vital necessity to human beings and one of the most important resources to development of nations, has been either scarce or in large state of degradation in many places in the world, including Brazil. The main challenge is the sustainable management of water supplies and demand in order to allow the current and coming generations to use it as well. The supply management implies policies of identification and development of new sources of water and demand, introduction of instruments to promote its conservation and efficient use. In Brazil, regulations about this subject were created in the 30s, based on a centered model and under strong influence of electrical sector. Along with the Brazilian Constitution in 1988, a new system of management was created: integrated, democratic and decentralized, having the hydrographic basin as reference to management. This system combines the application of several different mechanisms of regulation, using command-and-control approach, economic instruments and environmental education. The planning is shared among government, civil organizations and users, with integrated decisions about development, use of water, sanitation and environment, involving a diversity of agents with contradictory objectives, which means ones interests are the others regulators. This article analyses the implementation of the system in Brazil and in State of São Paulo, discuss its basic features, delineates the differences between both models, points the main problems and how they have been treated.
\end{abstract}

Key words: Natural resources, freshwater, public policy, integrated management, basin committees.

Secretaria da Economia e Planejamento do Estado de São Paulo e Centro Universitário Fundação Escola de Comércio Álvares Penteado (Unifecap). E-mail: jgomes@ fecap.br.

** Departamento de Administração da Produção e Operações da Escola de Administração de Empresas de São Paulo da Fundação Getulio Vargas (FGV/Eaesp-POI), Centro de Estudos de Gestão Empresarial e Meio Ambiente (FGV/Eaesp-Ceama) e Unifecap. E-mail: jcbarbieri@ fgvsp.br.

Artigo recebido em dezembro de 2003 e aceito em fevereiro de 2004. 


\section{Introdução}

A temática ambiental se tornou uma preocupação central, por diversas razões. Os principais motivos são a constatação de que são insustentáveis os padrões correntes de uso dos recursos naturais, a descoberta da vulnerabilidade do ser humano diante das suas próprias ações e a maior politização em torno da questão ambiental. Entre as questões ambientais mais polêmicas se destaca a gestão da água doce, um bem vital para todos os seres vivos e um dos principais recursos para o desenvolvimento dos países. Entretanto, esse bem é escasso ou está em grande estado de degradação em muitas regiões do planeta, até mesmo no Brasil, onde sua regulamentação começou no início da década de 1930, baseada num modelo centralizado e sob forte influência do setor de energia elétrica. Com a atual Constituição Federal começa a ser criado um novo modelo de gestão dos recursos hídricos, de modo integrado e ao mesmo tempo descentralizado, tendo a bacia hidrográfica como unidade administrativa e órgãos colegiados, em diferentes níveis, como instâncias decisórias. Esse artigo irá abordar os principais problemas quanto aos recursos hídricos no Brasil e no estado de São Paulo e, em seguida, mostrar as principais características dos atuais modelos nacional e paulista de gerenciamento desses recursos, ressaltando as diferenças em relação ao modelo anterior.

O objetivo deste artigo é discutir esse tema, do ponto de vista das soluções adotadas no estado de São Paulo, com a implementação da Lei $\mathrm{n}^{\mathbf{0}} \mathbf{7 . 6 6 3}$, de 30 de dezembro de 1991, que instituiu a Política Estadual de Recursos Hídricos e o Sistema Integrado de Gerenciamento de Recursos Hídricos (SIGRH). Inicialmente, será apresentado um resumo da atual situação dos recursos hídricos, no mundo e no Brasil, e como essa situação é tratada no âmbito global. Depois, serão discutidos os principais aspectos da política pública no estado de São Paulo, tendo como foco central o SIGRH. Os principais componentes desse sistema serão analisados, com destaque para os comitês de bacias hidrográficas. Finalmente, serão discutidos os conflitos socioambientais na condução desses comitês e os problemas de interface com o Sistema Nacional de Gerenciamento de Recursos Hídricos (SNGRH), instituído pela Lei nº̄, de 9.433, de 08 de janeiro de 1997.

\section{Água doce e recursos hídricos}

Segundo Rebouças (2002), "água" é o elemento natural desvinculado de qualquer utilização e "recurso hídrico" a parte da água passível de utilização, portanto, dotada de valor econômico. O planeta Terra tem dois terços de sua superfície cobertos por água (360 milhões $\mathrm{Km}^{2}$ de um total de 510 milhões $\mathrm{Km}^{2}$ ). Contudo, mais de $98 \%$ da água disponível é salgada, e dos $2 \%$ de água doce - considerada de baixa salinidade - restantes, mais de 68,9\% estão dispostos em geleiras, 29,9\% estão em reservatórios subterrâneos profundos - consequientemente, de difícil acesso - e apenas 1,2\% está disponível em rios e lagos (SENRA, 2001, p.133). No Brasil, o Conselho Nacional do Meio Ambiente (Conama) classifica a água em três categorias: a água doce é a que apresenta uma concentração de sal inferior a $0,5 \%$, a água salobra apresenta uma concentração de sal que varia de $0,5 \%$ a $30 \%$ e a água salgada apresenta uma concentração superior a 30\% (CONAMA, 1986).

Simultaneamente ao aquecimento terrestre, a escassez de água doce tem sido considerada um dos problemas ambientais mais graves e complexos. O uso de água cresce continuamente em todo mundo, em particular na agricultura irrigada (UICN, PNUMA e WWF, 1991, p.148), e no Brasil a idéia de abundância reforçou a cultura do desperdício (REBOUÇAS, 1999, p.201). A maneira como os recursos hídricos são utilizados e a degradação desses recursos vem provocando uma crise de grandes proporções em muitos países, especialmente nos grandes centros urbanos. Esses problemas poderão se intensificar com a mudança climática decorrente do aumento da concentração de gases de efeito estufa. Particularmente nas regiões áridas e semi-áridas, o aumento da temperatura do planeta entre $1{ }^{\circ} \mathrm{C}$ e $2^{\circ} \mathrm{C}$, combinado com uma redução de $10 \%$ no índice pluviométrico, poderá reduzir o escoamento anual em até 70\% (UICN, PNUMA, WWF, 1991, p.149).

A água doce é um recurso material limitado e com múltiplas funções; portanto, com diferentes tipos de usos. Para o abastecimento humano, a água é matéria-prima; para a atividade industrial e de irrigação, a água pode ser insumo e matéria-prima; para a navegação, a água é leito navegável; para atividades de recreação e lazer, a água é parte da beleza cênica; para as atividades de pesca, a água é o meio onde vivem as espécies; para o esgotamento de efluentes urbanos e industriais, a água é corpo diluidor e para a produção de energia é 
necessário explorar os movimentos da água transformando energia cinética em elétrica (GARRIDO, 2000, p.58). Como equacionar os conflitos inerentes aos diversos tipos de uso dos recursos hídricos, muitas vezes envolvendo interesses contraditórios?

Essa pergunta tem levado à reflexão, governantes, empresários, ativistas de entidades civis e de instituições supranacionais. Os problemas relacionados com a água doce têm sido objeto de diversas conferências multilaterais, como as que estão citadas no quadro 1. É necessário ressaltar que a Organização Mundial da Saúde (OMS) considera que para uma vida saudável é necessário um mínimo de $1.500 \mathrm{~m}^{3}$ de água por habitante/ano. Isso significa mais 9 trilhões $\mathrm{m}^{3}$ /ano apenas para consumo humano, fora as necessidades de água para as demais espécies e para outros tipos de uso humano como irrigação, navegação, processos industriais, limpeza pública, geração de energia etc.

De acordo com um diagnóstico apresentado na Conferência Internacional sobre Água Doce, em Bonn, em 2001, cerca de 1,2 bilhão de pessoas vivem sem acesso à água em quantidade e qualidade necessárias para uma vida saudável e digna; 2,5 bilhões carecem de saneamento adequado e 4 milhões, principalmente crianças, morrem todos os anos de disenteria, amebíase e outras doenças associadas à água de má qualidade. Dessa forma, mantido o padrão atual de uso e degradação da água, esse quadro tende a se agravar, pois, estima-se que por volta de 2030 a Terra contará com 2 bilhões de pessoas a mais, a maioria vivendo nas grandes cidades situadas em países pobres, principalmente, na Ásia, na África, no Oriente Médio e na América Latina (PETRELLA, 2002).

Quadro 1

Principais eventos intergovernamentais recentes sobre água doce

EVENTO ANO

Convenção Relativa às Zonas Úmidas de Importância Internacional - Ramsar 1975

Conferência das Nações Unidas sobre Água - Mar del Plata 1977

Reunião Consultiva Mundial sobre Água Potável e Saneamento para o Decênio de 1990-99 1990

Nova Déli

Convenção sobre a Proteção e Uso de Cursos d'Água e Lagos Internacionais - Helsinque 1992

Conferência das Nações Unidas sobre Desenvolvimento e Meio Ambiente 1992

Conferência Internacional sobre Água e Meio Ambiente - Dublin 1992

Conferência Ministerial sobre Água Potável e Saneamento Ambiental - Noordwijk 1994

Conferência Intergovernamental para a Adoção de um Programa de Ação Mundial para a 1995

Proteção do Meio Ambiente Marinho decorrente das Atividades Realizadas em Terra.

II Conferência das Nações Unidas sobre Assentamentos Humanos (Habitat II) 1996

$\begin{array}{ll}\text { I Fórum Mundial da Água - Marrakech } & 1997\end{array}$

II Fórum Mundial da Água - Haia $\quad 2000$

Conferência Internacional sobre Água Doce - Bonn (Dublin + 10) 2001

Cúpula Mundial sobre Desenvolvimento Sustentável (Rio + 10) - Johannesburgo 2002

III Fórum Mundial sobre Água (Kyoto) 2003

Esses fatos colocam a água no centro dos principais conflitos humanos, seja no âmbito internacional - uma vez que muitas bacias hidrográficas e aqüíferos são compartilhados por diversos países -, seja em níveis nacionais, subnacionais e locais. Segundo Petrella (2002), estudos realizados em 1990 por Walter H. Corson identificaram 155 bacias compartilhadas por dois países; 36 por três países e 23 bacias por um número de até 12 países. O quadro 2 apresenta uma visão sintetizada de algumas das principais zonas de conflito envolvendo o uso de recursos hídricos no mundo. Os recursos hídricos não são as únicas causas dos conflitos listados nesse quadro. Algumas vezes são a principal causa dos conflitos; em outras, consequiência de conflitos que se originam de disputas quase sempre envolvendo a luta por hegemonia política, econômica ou cultural; quando não estão relacionados com tensões causadas por uma certa irresponsabilidade de lideranças políticas, econômicas e religiosas em buscar a paz de forma consistente, reconhecendo interesses e necessidades das diversas partes 
envolvidas. Como exemplo, pode-se destacar os conflitos entre os países árabes (Síria, Jordânia, Palestina e Líbano) e Israel, envolvendo o rio Jordão. Em grande parte, a principal causa do problema remonta ao fim da II Guerra Mundial, quando os líderes dos países aliados, vencedores, atenderam a uma justa reivindicação do povo judeu, criando o estado de Israel, sem, contudo, atender às também justas reivindicações do povo árabe, principalmente dos palestinos (PETRELLA, 2002).

Conflitos internacionais são complexos, especialmente, quando envolvem a apropriação de um recurso para o qual não existem substitutos. Requerem ações coordenadas no plano internacional, que adotem o princípio da solidariedade no lugar da competição, estabelecendo um novo padrão de utilização dos recursos hídricos, baseado no uso justo. Entretanto, também podem existir conflitos no âmbito interno dos países, principalmente, quando o uso dos recursos hídricos adquire um caráter competitivo e, portanto, mutuamente excludente, tais como: entre uso urbano ou rural, abastecimento humano ou industrial, satisfação das necessidades de regiões altamente desenvolvidas ou das necessidades de desenvolvimento de regiões periféricas.

Quadro 2

Algumas zonas de conflitos envolvendo recursos hídricos

\begin{tabular}{lll}
\hline PAÍSES & RIOS E LAGOS & QUESTÕES PRINCIPAIS \\
\hline Egito, Etiópia e Sudão & Rio Nilo & $\begin{array}{l}\text { Depósitos aluviais, desvios de água, enchentes, } \\
\text { irrigação, cotas internacionais }\end{array}$ \\
\hline Nigéria e Chade & Lago Chade & Barragens \\
\hline Namíbia, Angola e Botsuana & Rio Okavango & Desvio de água \\
\hline Argentina e Brasil & Rio Paraná & Barragens e inundações \\
\hline EUA e México & Rios Colorado e Grande & $\begin{array}{l}\text { Poluição química, cotas internacionais, níveis de } \\
\text { salinidade }\end{array}$ \\
\hline EUA e Canadá & Baía de St. Lawrence & Obras hidráulicas \\
\hline Bolívia e Chile & Rio Lauca & Barragens e salinidade \\
\hline Equador e Peru & Rio Cenepa & Distribuição de água \\
\hline Bangladesh, Índia e Nepal & $\begin{array}{l}\text { Ganges, Farakka e } \\
\text { Brahmaputra }\end{array}$ & $\begin{array}{l}\text { Depósitos aluviais, barragens, enchentes, irrigação e } \\
\text { cotas internacionais }\end{array}$ \\
\hline $\begin{array}{l}\text { Camboja, Laos, Tailândia e } \\
\text { Vietnã }\end{array}$ & Rio Mekong & Enchentes e cotas internacionais \\
\hline Tibete, China e Birmânia & Rio Salween & Depósitos aluviais e enchentes \\
\hline Hungria e Eslováquia & Rio Danúbio & Poluição industrial \\
\hline $\begin{array}{l}\text { Alemanha e República } \\
\text { Tcheca }\end{array}$ & Rio Elba & Poluição industrial e níveis de salinidade \\
\hline Bélgica e Holanda & Mosel e Escaut & Poluição industrial \\
\hline Hungria e Romênia & Rio Somes & Distribuição de água \\
\hline Espanha e Portugal & Rio Tejo & Distribuição de água \\
\hline Iraque e Síria & Rios Tigre e Eufrates & Cotas internacionais e níveis de salinidade \\
\hline $\begin{array}{l}\text { Israel, Jordânia, Líbano e } \\
\text { Síria }\end{array}$ & Rios Jordão, Litani e \\
\hline Yarmuk & Desvios de água e cotas internacionais \\
\hline
\end{tabular}

Fonte: Petrella (2002)

\section{Água doce no Brasil}

A oferta de recursos hídricos no Brasil pode ser considerada generosa, embora caracterizada por algumas assimetrias entre a disponibilidade e a necessidade. Segundo Senra (2001, p.133), o Brasil possui 12\% das reservas de água do planeta, enquanto abriga 2,8\% da população mundial (167 milhões de habitantes). A China com $25 \%$ da população, possui $10 \%$ das reservas de água, e o Japão, com 2,5\% da população mundial, possui o equivalente a $1 \%$ das reservas. Essa condição, segundo Rebouças (1999, p.200), situa o Brasil entre as nações mais ricas em água doce do planeta, com $54 \%\left(5.600 \mathrm{~km}^{3} / \mathrm{ano}\right)$ do deflúvio total dos rios da América do Sul $\left(10.377 \mathrm{~km}^{3} / \mathrm{ano}\right)$ ou $14 \%$ do mundo $\left(40.673 \mathrm{~km}^{3} / \mathrm{ano}\right)$. 
A produção hídrica superficial em território brasileiro é de $168.790 \mathrm{~m}^{3} / \mathrm{s}$, chegando a $257.790 \mathrm{~m}^{3} / \mathrm{s}$ quando se considera a vazão da bacia amazônica procedente de território estrangeiro (NOVAES, 2000, p.59). Contudo, existem grandes disparidades entre a produção hídrica e a concentração demográfica. A região amazônica, com um adensamento demográfico de 2 a 5 habitantes $/ \mathrm{km}^{2}$, responde por $78 \%$ da produção hídrica nacional; a bacia do rio São Francisco (densidade de 5 a 25 habitantes $/ \mathrm{km}^{2}$ ) corresponde a apenas 1,7\% da descarga hídrica total, enquanto a bacia do rio Paraná (densidade de 25 a mais de 100 habitantes $/ \mathrm{km}^{2}$ ) corresponde a $6 \%$ da produção hídrica total (REBOUÇAS, 1999, p.201). Esses dados mostram que menos de $20 \%$ da descarga hídrica nacional abastece cerca de $95 \%$ da população, enquanto $80 \%$ dessa produção é originada de regiões ocupadas por apenas $5 \%$ da população. Isso quer dizer que embora o Brasil tenha uma das maiores reservas de água doce do planeta, existem regiões situadas abaixo dos padrões mínimos, em decorrência das disparidades entre a produção hídrica e o adensamento demográfico.

O crescimento demográfico urbano dos últimos 30 anos é um fator importante de pressão sobre os recursos hídricos. No período 1970-2000, a taxa de urbanização passou de menos de $56 \%$ para mais de $81 \%$ (IBGE, 2000). São 25 aglomerados urbanos com população superior a 500 mil habitantes e $12 \mathrm{com}$ mais de 1 milhão. Essa mudança na distribuição espacial da população brasileira se tornou um fator relevante para a agenda ambiental do país, sobretudo a partir da década de 1990, quando se pode considerar que o novo padrão de distribuição da população passou a ser mais importante que o crescimento demográfico em si (NEDER, 2002). A tabela 1 mostra a situação dos recursos hídricos nas unidades federativas brasileiras, comparativamente aos países europeus. Um índice de disponibilidade acima de $20.000 \mathrm{~m}^{3}$ habitante/ano revela uma situação de abundância e, no outro extremo, é considerado situação crítica de escassez um índice de disponibilidade abaixo de $1.500 \mathrm{~m}^{3} /$ habitante/ano.

Como mostra a tabela, das 27 unidades federativas brasileiras, 11 apresentam uma oferta de água abundante, com disponibilidade hídrica oscilando entre $39 \mathrm{mil} \mathrm{e} 1.747 .010 \mathrm{~m}^{3} /$ habitante/ano. Em comparação com os países europeus, os que possuem maior disponibilidade hídrica apresentam uma relação que varia de $21.800 \mathrm{~m}^{3}$ a $22.600 \mathrm{~m}^{3} /$ habitante/ano. No Brasil, quatro unidades federativas apresentam uma situação considerada muito rica, duas ricas e duas em condição de equilíbrio em relação ao que a OMS considera adequado para a satisfação da vida em comunidade e para o exercício das atividades humanas e sociais. Seis unidades federativas apresentam situação pobre (disponibilidade inferior a $2.500 \mathrm{~m}^{3} /$ habitante/ano) e duas possuem situação crítica de escassez (abaixo de $1.500 \mathrm{~m}^{3} /$ habitante/ano). O estado de São Paulo apresenta uma situação de equilíbrio, mas isso apenas quando se considera a disponibilidade agregada de água. 
Tabela 1

Disponibilidade de recursos hídricos no Brasil e na Europa

\begin{tabular}{|c|c|c|c|c|}
\hline $\begin{array}{l}\text { SITUAÇÃO } \\
\left(\mathbf{m}^{\mathbf{3}} / \mathbf{h a b} / \mathbf{a n o}\right)\end{array}$ & PAÍS & $\begin{array}{c}\text { DISPONIBILIDADE } \\
\left(\mathbf{m}^{3} / \mathrm{hab} / \mathbf{a n o}\right)\end{array}$ & $\begin{array}{c}\text { UNIDADE } \\
\text { FEDERATIVA }\end{array}$ & $\begin{array}{c}\text { DISPONIBILIDADE } \\
\left(\mathbf{m}^{3} / \mathbf{h a b} / \mathbf{a n o}\right)\end{array}$ \\
\hline \multirow{11}{*}{$\begin{array}{l}\text { Abundância } \\
>20.000\end{array}$} & & & Roraima & 1.747 .010 \\
\hline & & & Amazonas & 878.929 \\
\hline & & & Amapá & 678.929 \\
\hline & & & Acre & 369.305 \\
\hline & & & Mato Grosso & 258.242 \\
\hline & & & Pará & 217.058 \\
\hline & & & Tocantins & 137.666 \\
\hline & & & Rondônia & 132.818 \\
\hline & & & Goiás & 39.185 \\
\hline & Finlândia & 22.600 & Mato Grosso do Sul & 39.185 \\
\hline & Suécia & 21.800 & Rio Grande do Sul & 20.798 \\
\hline \multirow{4}{*}{$\begin{array}{l}\text { Muito rica } \\
>10.000\end{array}$} & Irlanda & 14.000 & Maranhão & 17.184 \\
\hline & & & Santa Catarina & 13.662 \\
\hline & Luxemburgo & 12.500 & Paraná & 13.431 \\
\hline & Áustria & 12.000 & Minas Gerais & 12.325 \\
\hline \multirow{3}{*}{$\begin{array}{l}\text { Rica } \\
>5.000\end{array}$} & Países Baixos & 6.100 & Piauí & 9.608 \\
\hline & Portugal & 6.100 & Espírito Santo & 7.235 \\
\hline & Grécia & 5.900 & & \\
\hline \multirow{3}{*}{$\begin{array}{l}\text { Equilíbrio } \\
>2.500\end{array}$} & França & 3.600 & Bahia & 3.028 \\
\hline & Itália & 3.300 & São Paulo & 2.913 \\
\hline & Espanha & 2.900 & & \\
\hline \multirow{6}{*}{$\begin{array}{l}\text { Pobre } \\
<2.500\end{array}$} & Reino Unido & 2.200 & Ceará & 2.436 \\
\hline & Alemanha & 2.000 & Rio de Janeiro & 2.315 \\
\hline & Bélgica & 1.900 & Rio Grande do Norte & 1.781 \\
\hline & & 2 & Distrito Federal & 1.752 \\
\hline & & + & Alagoas & 1.751 \\
\hline & & $\mathrm{mar}$ & Sergipe & 1.743 \\
\hline \multirow{2}{*}{$\begin{array}{l}\text { Situação } \\
\text { crítica } \\
<1.500\end{array}$} & & & Paraíba & 1.437 \\
\hline & & & Pernambuco & 1.320 \\
\hline
\end{tabular}

Fonte: adaptada de Thame (2000).

\section{A água doce no estado de São Paulo}

Segundo dados da Secretaria de Recursos Hídricos do Estado de São Paulo, cerca de $86 \%$ do território do estado está localizado na bacia do rio Paraná. A quantidade de água é considerada boa, em grande parte por causa dos aqüíferos situados principalmente na região oeste. A intensa utilização desses aqüíferos, tanto para o abastecimento urbano, quanto para uso industrial, é fonte de grande preocupação por parte dos órgãos gestores estaduais que buscam disciplinar o seu uso. Quanto ao uso da água, podem ser constatadas grandes assimetrias entre as diversas bacias hidrográficas. Das 22 bacias existentes, 12 apresentam um consumo de água inferior a $10 \%$ da disponibilidade, três apresentam consumo que varia entre $10 \%$ e $30 \%$ da disponibilidade, três consomem entre $30 \%$ e $50 \%$, e em outras três, entre $50 \%$ e $99 \%$. Na bacia do Alto Tietê, onde está localizada a Grande São Paulo, já se constata vazão superior à disponibilidade hídrica. Isso significa que para suprir as necessidades de água da região é necessário transportá-la por meio de dutos de outras regiões do estado. Nesse caso, a água transportada é coletada na bacia hidrográfica formada pelos rios Piracicaba, Capivari e Jundiaí, captada nas proximidades de Bragança Paulista e despejada na bacia do Rio Tietê pelo Sistema Cantareira. 
Entre as causas da necessidade de captar água em outra bacia estão, entre outras, o elevado índice demográfico da bacia do Alto Tietê, a poluição das águas da região da Grande São Paulo e também a baixa disponibilidade hídrica natural da região, uma vez que se trata de uma região formadora de rios.

Thame (2000, p.12) considera que no estado de São Paulo quatro bacias hidrográficas apresentam uma situação crítica. Na bacia do Alto Tietê, a disponibilidade hídrica é de $200 \mathrm{~m}^{3} /$ habitante/ano; na bacia dos rios Piracicaba/Capivari/Jundiaí, é de $400 \mathrm{~m}^{3} /$ habitante/ano; na bacia do rio Turvo/Grande, $900 \mathrm{~m}^{3}$ e na bacia do Mogi-Guaçu, $1.500 \mathrm{~m}^{3}$. Contudo, especialistas consideram elevado qualquer índice de uso que se aproxime dos $50 \%$ da disponibilidade. A tabela 2 apresenta uma síntese com as principais características das 22 bacias hidrográficas do estado de São Paulo, destacando o nome que dá título à bacia, o número de municípios que a compõe, sua área geográfica, população total, o percentual de uso de recursos hídricos em relação à disponibilidade, o tipo de bacia e a principal atividade consumidora de recursos hídricos na bacia.

Tabela 2

Caracterização das bacias hidrográficas do estado de São Paulo

\begin{tabular}{|c|c|c|c|c|c|c|}
\hline BACIA & MUNICÍPIOS & $\begin{array}{r}\text { ÁREA } \\
\left(\mathbf{k m}^{2}\right)\end{array}$ & POPULAÇÃO & $\begin{array}{r}\text { VAZÃO/ } \\
\text { DISPONIBI- } \\
\text { LIDADE }\end{array}$ & $\begin{array}{r}\text { TIPO DE } \\
\text { BACIA } \\
\text { (Lei 9.034/94) }\end{array}$ & $\begin{array}{r}\text { PRINCIPAL } \\
\text { USO }\end{array}$ \\
\hline MANTIQUEIRA & 3 & 642 & 50.766 & - de $10 \%$ & Conservação & $\begin{array}{l}\text { Urbano e } \\
\text { Irrigação }\end{array}$ \\
\hline PARAÍBA DO SUL & 34 & 14.396 & 1.493 .415 & $10 \%$ a $30 \%$ & Industrial & Irrigação \\
\hline LITORAL NORTE & 4 & 1.977 & 173.475 & - de $10 \%$ & Conservação & Urbano \\
\hline PARDO & 23 & 9.606 & 880.117 & $30 \%$ a $50 \%$ & $\begin{array}{r}\text { Em } \\
\text { industrialização }\end{array}$ & Irrigação \\
\hline PIRACICABA & 58 & 13.897 & 3.867 .047 & $50 \%$ a $99 \%$ & Industrial & $\begin{array}{l}\text { Urbano e } \\
\text { Industrial } \\
\end{array}$ \\
\hline ALTO TIETÊ & 34 & 6.648 & 16.442 .671 & + de $100 \%$ & Industrial & Urbano \\
\hline $\begin{array}{l}\text { BAIXADA } \\
\text { SANTISTA }\end{array}$ & 9 & 2.373 & 1.310 .858 & $30 \%$ a $50 \%$ & Industrial & Industrial \\
\hline SAPUCAÍ/GRANDE & 22 & 9.937 & 572.252 & $30 v$ a $50 \%$ & $\begin{array}{r}\text { Em } \\
\text { industrialização }\end{array}$ & Irrigação \\
\hline MOGI-GUAÇU & 38 & 13.601 & 1.202 .705 & $50 \%$ a $99 \%$ & $\begin{array}{r}\text { Em } \\
\text { industrialização }\end{array}$ & $\begin{array}{r}\text { Industrial e } \\
\text { irrigação }\end{array}$ \\
\hline TIETÊ-SOROCABA & 34 & 12.018 & 1.373 .765 & $-10 \%$ & Industrial & $\begin{array}{r}\text { Industrial e } \\
\text { irrigação }\end{array}$ \\
\hline $\begin{array}{l}\text { RIBEIRA DE } \\
\text { IGUAPE }\end{array}$ & 23 & 17.264 & 320.285 & - de $10 \%$ & Conservação & Industrial \\
\hline $\begin{array}{l}\text { BAIXO PARDO/ } \\
\text { GRANDE }\end{array}$ & 12 & 7.091 & 304.485 & - de $10 \%$ & $\begin{array}{r}\text { Em } \\
\text { industrialização }\end{array}$ & Irrigação \\
\hline TIETÊ/JACARÉ & 34 & 15.808 & 1.222 .124 & - de $10 \%$ & $\begin{array}{r}\text { Em } \\
\text { industrialização }\end{array}$ & Irrigação \\
\hline $\begin{array}{l}\text { ALTO } \\
\text { PARANAPANEMA }\end{array}$ & 34 & 20.663 & 630.379 & - de $10 \%$ & Conservação & Irrigação \\
\hline TURVO/GRANDE & 64 & 17.173 & 1.051 .461 & $50 \%$ a $99 \%$ & Agropecuária & Irrigação \\
\hline TIETÊ/BATALHA & 33 & 13.384 & 433.932 & - de $10 \%$ & Agropecuária & Irrigação \\
\hline $\begin{array}{l}\text { MÉDIO } \\
\text { PARANAPANEMA }\end{array}$ & 42 & 17.552 & 583.544 & - de $10 \%$ & Agropecuária & $\begin{array}{r}\text { Industrial e } \\
\text { irrigação }\end{array}$ \\
\hline $\begin{array}{l}\text { SÃO JOSÉ DOS } \\
\text { DOURADOS }\end{array}$ & 25 & 6.142 & 207.716 & $10 \%$ a $30 \%$ & Agropecuária & Irrigação \\
\hline BAIXO TIETÊ & 42 & 18.621 & 655.333 & - de $10 \%$ & Agropecuária & Irrigação \\
\hline AGUAPEÍ & 32 & 23.204 & 337.214 & $10 \%$ a $30 \%$ & Agropecuária & Irrigação \\
\hline PEIXE & 26 & 12.393 & 358.829 & - de $10 \%$ & Agropecuária & Irrigação \\
\hline PONTAL & 24 & 13.365 & 429.362 & - de $10 \%$ & Agropecuária & Irrigação \\
\hline
\end{tabular}

Fonte: Departamento Estadual de Águas e Energia Elétrica de São Paulo - Secretaria de Estado do Meio Ambiente e Lei nำ 9.034/94. 
Na tabela 2, a coluna "principal uso" indica a atividade que mais consome recursos hídricos na bacia hidrográfica em questão. Contudo, essa informação não define nem o tipo, nem o perfil da bacia hidrográfica. Em uma região altamente industrializada, como por exemplo, a Região Metropolitana de São Paulo, o principal uso é o abastecimento humano. Em contraste, a região do Vale do Ribeira (bacia de conservação), muito pouco industrializada, tem como principal consumo, exatamente, a indústria. Isso ocorre porque a região é pouco habitada e os sistemas públicos de abastecimento são ainda incipientes. Desse modo, a pouca atividade industrial existente nessa bacia consome mais água que a população servida pelos sistemas públicos de abastecimento. As bacias de conservação recebem essa designação por estarem situadas em áreas de proteção ou preservação ambiental. São exemplos as bacias do rio Ribeira de Iguape, litoral norte, Mantiqueira e Alto Paranapanema. Bacias industriais são aquelas que estão situadas em áreas de elevada industrialização. Bacias em industrialização estão situadas em áreas onde há um equilíbrio entre o consumo de água em atividades industriais e para o abastecimento humano, com tendência ao crescimento industrial, como por exemplo, a bacia do Mogi-Guaçu.

Como se verifica na tabela 2, a irrigação constitui o principal uso dos recursos hídricos em São Paulo. O que era de se esperar, pois o estado tem na agricultura irrigada uma das suas principais riquezas. De acordo com cálculos elaborados (a pedido dos autores) por Antônio Carlos Macedo, ex-presidente da Cetesb, hoje fruticultor, uma área de 200 hectares com um único pivô central de irrigação consome 5 litros de água/ $\mathrm{m}^{2}$ ou $10.000 \mathrm{~m}^{2} /$ dia, correspondendo a uma retirada de 1 milhão de litros de água/dia. Técnicos da Secretaria do Meio Ambiente do Estado de São Paulo entrevistados apontam a produção de açúcar e de bebidas como duas outras atividades econômicas responsáveis por elevado consumo de água. Uma usina de açúcar consome cerca de $3 \mathrm{~m}^{3}$ de água/s. Essa água é usada, sobretudo, para lavar o bagaço da cana e extrair o açúcar que nele fica retido. Desse processo resulta a vinhaça, uma água altamente tóxica que tem sido usada como um fertilizante, o que minimiza a degradação ambiental em comparação com a prática anterior de jogar esse resíduo nos corpos d'água próximos às usinas. O consumo de uma única usina de açúcar, conforme seu porte, pode corresponder ao abastecimento humano de uma cidade com 100 mil habitantes. Fortaleza, por exemplo, com cerca de 300 mil habitantes, consome $3 \mathrm{~m}^{3}$ de água/s.

No setor industrial, ainda segundo técnicos da Secretaria do Meio Ambiente do Estado de São Paulo, a indústria de cerveja é a principal responsável pela captação de águas subterrâneas. Do total captado, apenas $20 \%$ seriam utilizados na produção de cerveja e refrigerantes. Os outros $80 \%$ dessa água extremamente pura são utilizados em processos de limpeza. A tabela 3 apresenta a demanda total de água no estado de São Paulo por tipo de uso e fontes de captação, verificados em 1996, e que corresponde à utilização de 17,8\% da disponibilidade hídrica do estado. Visto de uma forma agregada, o consumo é baixo e parece não preocupar. Contudo, como mostra a tabela 2 , há uma grande disparidade entre as diferentes bacias hidrográficas, sendo que algumas já apresentam elevados níveis de saturação e outras com o consumo aproximando-se da margem de segurança.

Tabela 3

Captação e uso de recursos hídricos no estado de São Paulo

\begin{tabular}{lccc}
\hline \multirow{2}{*}{ USO } & \multicolumn{3}{c}{ CAPTAÇÃO $\left(\mathbf{m}^{\mathbf{3}} / \mathbf{s}\right)$} \\
\cline { 2 - 4 } & SUPERFICIAL & SUBTERRÂNEA & TOTAL \\
\hline INDUSTRIAL & 90,5 & 4,6 & 95,1 \\
URBANO & 101,1 & 16,8 & 117,9 \\
IRRIGAÇÃO & 134,6 & 8,4 & 143,0 \\
TOTAL & 326,2 & 29,8 & 356,0 \\
\hline
\end{tabular}

Fonte: Departamento Estadual de Águas e Energia Elétrica (DAEE)

A tabela 4 apresenta uma projeção do consumo para o ano 2020, elaborada por técnicos do Departamento Estadual de Águas e Energia Elétrica (DAEE). O consumo previsto para aquele ano corresponde à utilização de $31,8 \%$ da disponibilidade hídrica do estado. Em princípio, a quantidade de água disponível se mantém constante. Porém, os especialistas apontam riscos de redução do volume de água em circulação em decorrência de diversos fatores, principalmente relacionados à elevação da temperatura da Terra. A disponibilidade de água 
é afetada também pela poluição dos mananciais. A crescente e descontrolada exploração dos aquíferos têm sido motivo especial de preocupação. A superexploração pode levar à redução da disponibilidade dessas fontes de água, pois, uma parte desses mananciais são fósseis e levam anos para se renovarem. Também há riscos de contaminação dessas reservas, para as quais, atualmente, não se conhece nenhuma tecnologia de despoluição disponível, principalmente, por causa da ausência de movimento das águas desses mananciais.

\section{Tabela 4}

Previsão de demanda de recursos hídricos no estado de São Paulo em 2020

\begin{tabular}{cc}
\hline USO & PROJEÇÃO $\mathbf{~ m}^{\mathbf{3}} / \mathbf{s}$ \\
\hline INDUSTRIAL & 137,2 \\
URBANO & 174,2 \\
IRRIGAÇÃO & 327,0 \\
TOTAL & 638,0 \\
\hline
\end{tabular}

Fonte: Departamento Estadual de Águas e Energia Elétrica (DAEE)

\section{O Sistema Nacional de Gerenciamento de Recursos Hídricos (SNGRH)}

O marco legal que instituiu o gerenciamento integrado dos recursos hídricos foi claramente fixado no inciso XIX do artigo 21 da Constituição Federal de 1988. A Política Nacional de Recursos Hídricos (PNRH), instituída pela Lei $\mathrm{n}^{-}$9.433, de 08 de janeiro de 1997, que regulamenta o artigo citado, está baseada nos seguintes fundamentos:

- a água é um bem de domínio público;

- a água é um recurso natural limitado, dotado de valor econômico;

- em situações de escassez, o uso prioritário dos recursos hídricos é o de atender ao consumo humano e dessedentar os animais;

- a gestão dos recursos hídricos deve sempre garantir o uso múltiplo das águas;

- a bacia hidrográfica é a unidade territorial para a implementação da PNRH e a atuação do SNGRH; e

- a gestão dos recursos hídricos deve ser descentralizada e contar com a participação do poder público, dos usuários e da comunidade (art. $1^{\circ}$ ).

Para implementar a Política Nacional de Recursos Hídricos e coordenar a gestão integrada desses recursos é que foi criado o Sistema Nacional de Gerenciamento de Recursos Hídricos, cujos componentes são mostrados na figura 1. O Conselho Nacional de Recursos Hídricos (CNRH) faz parte da estrutura do Ministério do Meio Ambiente (MMA) sendo, no tocante aos recursos hídricos, a sua instância decisória mais elevada. A presidência do conselho é reservada ao ministro do Meio Ambiente e a secretaria-executiva à Secretaria de Recursos Hídricos do mesmo ministério. O número de representantes da União é de, no máximo, metade mais um do total de membros do conselho. As principais atribuições do CNRH são:

- planejar e coordenar o uso de recursos hídricos, considerando os planos estaduais;

- arbitrar conflitos como última instância administrativa;

- deliberar sobre projetos que geram impacto em mais de um estado;

- aprovar a implantação de comitês de bacias em regiões de domínio federal; e

- estabelecer diretrizes para outorga e cobrança pelo uso de recursos hídricos. 
Figura 1

Componentes do Sistema Nacional de Gerenciamento de Recursos Hídricos

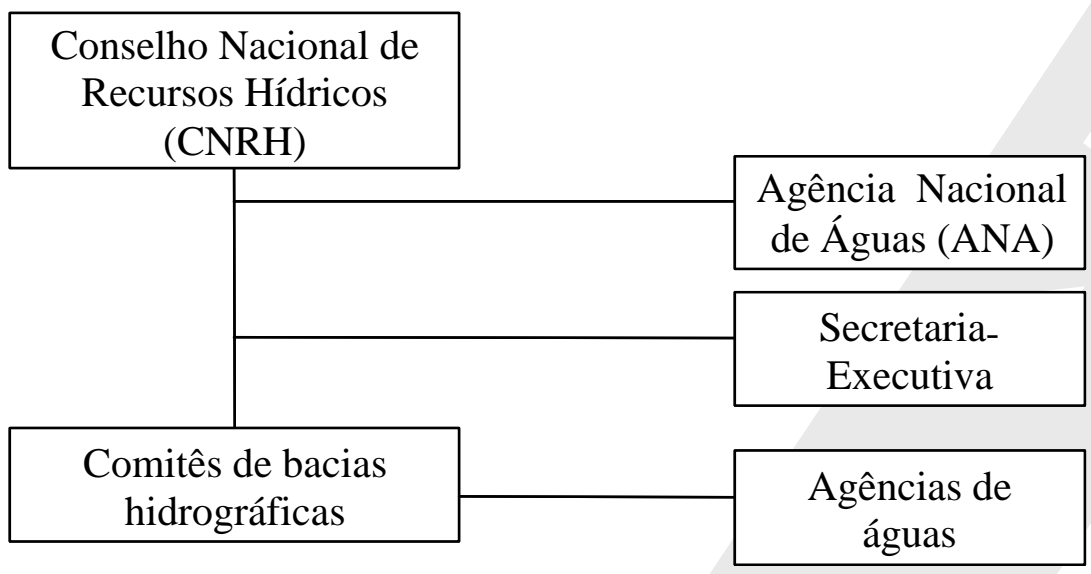

Os comitês de bacias hidrográficas em áreas de domínio federal possuem a seguinte composição: representantes da União, representantes das unidades federativas banhadas pela bacia hidrográfica (estados, Distrito Federal e municípios localizados na bacia) e representantes de organizações civis de recursos hídricos com atuação comprovada na bacia hidrográfica em questão. Em comitês de fronteira com outros países, é incluído, obrigatoriamente, um representante do Ministério das Relações Exteriores. Em comitês situados em áreas indígenas é obrigatória a inclusão de um representante da Fundação Nacional do Índio. Nos comitês de bacias em áreas de domínio federal, o número total de representantes do poder público (União, estados, Distrito Federal e municípios) é de, no máximo, metade do total. A outra metade é composta por representantes de entidades civis e de usuários.

Futuramente, cada comitê deverá contar com uma agência de bacia, a qual exercerá as funções de secretariaexecutiva e cujas principais atribuições são:

- manter balanço atualizado da disponibilidade de recursos hídricos na bacia, contemplando aspectos quantitativos e qualitativos;

- manter cadastro de usuários e, por delegação do órgão outorgante, no caso a Agência Nacional de Águas (ANA), cobrar pelo uso de recursos hídricos;

- analisar e emitir pareceres sobre projetos a serem financiados com recursos oriundos da cobrança;

- gerir o sistema nacional de informações sobre recursos hídricos em sua área de atuação;

- elaborar e propor ao plenário do comitê de bacia o plano de recursos hídricos da bacia;

- enquadrar os corpos de água em classes de uso; e

- propor ao plenário do comitê de bacia um plano para aplicação dos recursos arrecadados com a cobrança pelo uso dos recursos hídricos.

A Agência Nacional de Águas (ANA), criada pela Lei no 9.984, de 17 de julho de 2000, é uma autarquia vinculada ao Ministério do Meio Ambiente (MMA), com a finalidade de implementar a PNRH em sua esfera de atribuições (art. $3^{\circ}$ ). Entre outras atribuições, cabe à ANA:

- outorgar o direito de uso de recursos hídricos em corpos de água de domínio da União;

- fiscalizar o uso desses recursos;

- elaborar estudos técnicos para subsidiar a definição (pelo CNRH) dos valores a serem cobradas pelo uso de recursos hídricos de domínio da União, com base nos mecanismos e quantitativos sugeridos pelos comitês de bacias hidrográficas; 
- arrecadar, distribuir e aplicar receitas auferidas por intermédio da cobrança pelo uso de recursos hídricos $\left(\operatorname{art.} 3^{\circ}\right)$.

Alguns exemplos mostram como a ANA tem operado com respeito à cobrança pelo uso da água. Na bacia do rio Jaguaribe, no Ceará, como o volume de água somente poderia atender metade da demanda dos agricultores, os produtores do Baixo Jaguaribe passaram a pagar $\mathrm{R} \$ 0,01$ por mil litros de água, e essa arrecadação foi usada para indenizar os agricultores que ficaram sem água e trocaram suas culturas tradicionais -arroz e feijão, por exemplo -, que consomem muita água, por outras que consomem menos. A Agência Nacional de Águas definiu os valores a serem cobrados pelo uso da água da bacia do rio Paraíba do Sul (Resolução no ${ }^{0}$, de 2002), considerando os valores propostos pelo Comitê para a Integração da Bacia Hidrográfica do Paraíba do Sul (Deliberação Ceivap n⿳ำ 8 , de 2001). Os recursos serão aplicados na própria bacia, em projetos de despoluição das águas da bacia do Paraíba do Sul.

Como se vê, trata-se de um modo completamente novo de gerir um recurso natural, rompendo uma tradição de centralismo burocrático que vem desde as ordenações portuguesas e que continuou, no caso da água, com o Código de Águas de 1934 (Decreto n⿳ํㅡㄹ 24.643/34). Com a PNRH, as decisões sobre os recursos hídricos passam a ser descentralizadas, compartilhadas entre os usuários e os representantes do poder público, e os recursos gerados serão aplicados prioritariamente na bacia em que foram gerados (art. 22). Em grande parte, o sistema implantado pela União baseou-se no modelo paulista. O sistema paulista, por sua vez, baseou-se no modelo francês, que tem nos comitês de bacias suas instâncias decisórias básicas, ou seja, as principais decisões são tomadas pelos que estão sentindo os problemas e envolvidos em conflitos decorrentes do uso dos recursos da bacia. No modelo anterior, os conflitos eram resolvidos no âmbito dos órgãos especializados do Executivo federal, como o Departamento Nacional de Águas e Energia Elétrica, atendendo prioridades estabelecidas pelo poder central, onde a resolução de conflitos se dava conforme as forças locais e regionais e os interesses políticos em jogo.

\section{0 sistema de recursos hídricos do estado de São Paulo}

A PNRH só veio nove anos depois de promulgada a Constituição Federal. Diante desse atraso, diversos estados criaram suas políticas próprias, como é caso de São Paulo (Lei no 7.663/91), Ceará (Lei no 11.996/92), Minas Gerais (Lei no 11.504/94) e Rio Grande do Sul (Lei no 10.350/94). Embora o sistema paulista de gerenciamento de recursos hídricos tenha sido instituído antes da implantação do sistema nacional, não houve necessidade de se adaptar ao nacional, pois este se baseou na experiência paulista. Coerentemente com a Constituição Federal, também a Constituição do Estado de São Paulo (art. 205) determinou a implementação no estado do Sistema Integrado de Gerenciamento de Recursos Hídricos (SIGRH).

O início do desenvolvimento do sistema estadual remonta a 1987, quando se implantou o Conselho Estadual de Recursos Hídricos e o Comitê Coordenador do Plano Estadual de Recursos Hídricos. Eram entidades que funcionavam como parte da estrutura burocrática do estado, não contemplando a participação de outras partes interessadas, como a sociedade civil e os usuários. Desde então, diversas leis foram aprovadas no âmbito federal e, sobretudo, no estado de São Paulo, dando forma ao sistema atual. A tabela 5 apresenta uma cronologia de implantação do sistema paulista, destacando os acontecimentos mais importantes, dentre os quais, a promulgação da Lei $\mathrm{n}^{\mathbf{0}}$ 7.663, de 30 de dezembro de 1991, que serviu de exemplo para diversas legislações estaduais e para a própria legislação federal. 


\section{Estrutura do sistema de gerenciamento de recursos hídricos}

O Sistema Integrado de Gerenciamento de Recursos Hídricos do Estado de São Paulo, criado pela Lei $\mathrm{n}^{\circ}$ 7.663/91, implantou na administração pública estadual uma nova entidade política e administrativa, que trouxe grandes inovações de conteúdo e de princípios. O sistema rompeu com a hegemonia exercida pelo setor hidrelétrico na questão dos recursos hídricos desde o início do processo de industrialização brasileiro, com o Código de Águas de 1934; hegemonia consolidada a partir de 1964, quando a energia passou a ser o principal insumo da modernização industrial brasileira e as hidrelétricas se tornaram o maior vetor das grandes obras públicas. O sistema atual também inova ao romper com a tradicional fragmentação setorial da ação dos órgãos públicos, integrando numa mesma instância política deliberações relacionadas aos recursos hídricos, ao meio ambiente e ao saneamento.

Os recursos hídricos são considerados bem público e, portanto, de propriedade de todos, limitado, dotado de valor econômico, e cujo uso deve ser retribuído para gerar recursos financeiros suficientes para assegurar padrões aceitáveis de qualidade e quantidade para as gerações atuais e futuras. É estabelecida prioridade no uso da água para o abastecimento humano, a compatibilização dos usos com o desenvolvimento regional e a proteção ambiental. Quanto aos princípios, a qualificação da água como bem público é "desdobrada" em diretrizes claras para a gestão da quantidade e qualidade, como também nos esforços para que haja participação da sociedade, desvinculando a gestão de uma subordinação exclusiva às estruturas administrativas do Estado. Nesse aspecto, destacam-se os colegiados de gestão compostos por um número igual de representantes do Estado, do poder local e da sociedade civil. O Estado é convidado a abandonar o seu papel autoritário e paternalista, detentor de todo o poder decisório, passando a compartilhar suas tradicionais responsabilidades com os usuários de recursos hídricos, governos municipais e outras formas de organização da sociedade, como sindicatos e entidades não-governamentais. A bacia hidrográfica passa a ser a referência de planejamento e gerenciamento, o que também configura uma mudança significativa em termos de gestão descentralizada, retirando poderes de instâncias burocráticas estatais localizadas nos grandes e distantes centros urbanos. Nesse sentido, o sistema estadual é sustentado por uma estrutura formada por três instâncias articuladas, desde o nível mais alto do sistema até os comitês de bacias, que são as unidades de planejamento e gerenciamento. São elas: colegiados de gestão, suporte financeiro e comitê técnico. 
Tabela 5

Evolução do sistema de gerenciamento de recursos hídricos

\begin{tabular}{|c|c|}
\hline ANO & ACONTECIMENTOS \\
\hline 1987 & $\begin{array}{l}\text { - Implantação do Conselho Estadual de Recursos Hídricos } \\
\text { - Comitê Coordenador do Plano Estadual de Recursos Hídricos }\end{array}$ \\
\hline 1988 & $\begin{array}{l}\text { - Lei estadual no } 6.134 \text { sobre a preservação dos depósitos naturais de águas subterrâneas do estado } \\
\text { de São Paulo } \\
\text { - Constituição Federal determina a criação do Sistema Nacional de Recursos Hídricos. }\end{array}$ \\
\hline 1989 & $\begin{array}{l}\text { - Constituiçãa do Estado de São Paulo (art. 205) determina a criação do Sistema Integrado de } \\
\text { Gerenciamento de Recursos Hídricos (SIGRH) }\end{array}$ \\
\hline 1991 & $\begin{array}{l}\text { - Lei Estadual no } 7.663 \text { cria o Sistema Integrado de Gerenciamento de Recursos Hídricos no estado } \\
\text { de São Paulo } \\
\text { - Decreto no } 32.954 \text { divide o estado de São Paulo em } 22 \text { bacias hidrográficas, classificando-as em } \\
\text { quatro categorias: industrial, em industrialização, agropecuária e de conservação }\end{array}$ \\
\hline 1993 & $\begin{array}{l}\text { - Lei estadual no } 8.275 \text { cria a Secretaria Estadual de Recursos Hídricos } \\
\text { - Decreto estadual no } 37.300 \text { cria o Fundo Estadual de Recursos Hídricos (Fehidro) } \\
\text { - Implantação do primeiro comitê de bacia hidrográfica no estado de São Paulo abrangendo os rios } \\
\text { Piracicaba, Capivari e Jundiaí }\end{array}$ \\
\hline 1994 & $\begin{array}{l}\text { - Lei estadual no } 9.034 \text { sobre o Plano Estadual de Recursos Hídricos } \\
\text { - Adaptação, alterações na composição e implantação do Conselho Estadual de Recursos Hídricos } \\
\text { (tripartite) } \\
\text { - Implantação dos comitês das bacias hidrográficas do Alto Tietê, Baixo Tietê, Médio } \\
\text { Paranapanema e Paraíba/Mantiqueira }\end{array}$ \\
\hline 1995 & $\begin{array}{l}\text { - Implantação dos comitês das bacias hidrográficas do Sorocaba, Médio Tietê, Tietê/Jacaré, Baixada } \\
\text { Santista, Turvo Grande e Aguapeí/Peixe }\end{array}$ \\
\hline 1996 & $\begin{array}{l}\text { - Implantação dos comitês das bacias hidrográficas do Ribeira de Iguape, Baixo Pardo/Grande, } \\
\text { Sapucaí/Grande, Mogi-Guaçu, Pardo, Pontal do Paranapanema e Tietê/Batalha }\end{array}$ \\
\hline 1997 & $\begin{array}{l}\text { - Lei Federal no. } 9.433 \text { que, regulamentando o artigo } 21 \text { da Constituição Federal de 1988, institui a } \\
\text { Política e o Sistema Nacional de Recursos Hídricos } \\
\text { - Implantação dos comitês das bacias hidrográficas do São José dos Dourados, Litoral Norte }\end{array}$ \\
\hline 1998 & - Lei n⿳o 10.020, do estado de São Paulo, autoriza a criação das agências de bacias hidrográficas \\
\hline 2000 & $\begin{array}{l}\text { - Lei Federal no } 9.984 \text { cria a Agência Nacional de Águas (ANA) } \\
\text { - Projeto de Lei n⿳⺈ } 676 / 00 \text { substitui o Projeto de Lei nº } 20 / 88 \text { sobre a cobrança pelo uso de recursos } \\
\text { hídricos }\end{array}$ \\
\hline 2002 & $\begin{array}{l}\text { - O Conselho Nacional de Recursos Hídricos aprovou a cobrança pelo uso da água na bacia } \\
\text { hidrográfica do Paraíba do Sul, englobando partes dos estados de São Paulo, Minas Gerais e Rio } \\
\text { de Janeiro }\end{array}$ \\
\hline
\end{tabular}

\section{Conselho de Recursos Hídricos (CRH)}

Os colegiados de gestão são instâncias políticas, estratégicas e deliberativas, formadas em nível central pelo Conselho Estadual de Recursos Hídricos $(\mathrm{CRH})$ e, regionalmente, pelos comitês de bacias hidrográficas (CBHs). Os colegiados são compostos de forma paritária por representantes dos órgãos do governo do estado de São Paulo, governos municipais e representantes da sociedade civil. Nos comitês, o número de representantes varia segundo as características regionais e as decisões de cada bacia, também mantendo paridade entre os três segmentos.

O CRH é instância estratégica e deliberativa do Sistema Integrado de Gerenciamento de Recursos Hídricos. Basicamente, sua função é formular e acompanhar a implantação das políticas de recursos hídricos no estado. É composto por 33 membros com direito à voz e voto - representantes dos órgãos estaduais, dos municípios e da sociedade civil -, sendo 11 de cada segmento. Também integram o conselho, sem direito a voz e voto, três 
representantes das universidades estaduais oficiais (USP, Unesp e Unicamp), um representante do Ministério Público, sete de entidades e órgãos estaduais e os presidentes dos comitês de bacias hidrográficas. O quadro 3 mostra a composição do $\mathrm{CRH}$. A presidência do conselho é exercida pelo secretário estadual de Recursos Hídricos. A vice-presidência é ocupada pela secretária de Meio Ambiente. A representação dos municípios é alterada a cada dois anos. Os representantes da sociedade civil são escolhidos entre os membros das entidades cadastradas no conselho. Quando há mais de uma entidade cadastrada em um mesmo segmento, é escolhida uma para representar o segmento pelo período de um ano, podendo ser reconduzida uma vez.

\section{Comitê Coordenador do Plano Estadual de Recursos Hídricos (Corhi)}

O Corhi elabora o Plano Estadual de Recursos Hídricos, baseando-se no relatório de situação e nos planos de bacia, elaborados nas bacias hidrográficas. É constituído pelos órgãos estaduais responsáveis pelo gerenciamento de recursos hídricos; sendo que nos aspectos quantitativos, o órgão responsável é o DAEE, e nos aspectos qualitativos, a Cetesb. O comitê é o braço de apoio técnico dos colegiados de gestão. No plano descentralizado, ele elabora e propõe anualmente ao plenário do comitê de bacia o relatório de situação dos recursos hídricos e o plano de bacias - com diretrizes de uso, recuperação e proteção dos recursos hídricos em cada uma das 22 bacias hidrográficas de São Paulo. No plano central, o Corhi elabora e propõe ao conselho estadual o Plano Estadual de Recursos Hídricos, a partir da consolidação dos 22 planos de bacias. O plano estadual contém as diretrizes de uso dos recursos hídricos no estado para um período de quatro anos. O comitê coordenador é composto por uma secretaria-executiva, que lhe presta apoio administrativo, e grupos técnicos responsáveis pelo aprofundamento de estudos específicos e de 12 programas de caráter permanente. No âmbito dos comitês de bacias, técnicos dos municípios podem participar dos grupos técnicos. No plano central, podem participar os técnicos de outras secretarias de estado e órgãos a elas vinculados, além daquelas que integram o conselho permanente.

Como uma instância de apoio técnico, as propostas do Corhi são discutidas e decididas pelas instâncias políticas deliberativas. No plano descentralizado, essa instância política é o plenário do comitê de bacia e, no plano central, o Conselho de Recursos Hídricos. O processo se desenvolve nas seguintes etapas:

- o Corhi elabora o relatório de situação e propõe os planos de bacias nas 22 unidades de planejamento e gerenciamento;

- os plenários dos comitês de bacias deliberam sobre os planos apresentados pelo Corhi;

- o Corhi elabora e propõe o Plano Estadual de Recursos Hídricos a partir da consolidação e compatibilização dos 22 planos de bacias hidrográficas;

- o Conselho Estadual de Recursos Hídricos delibera sobre o plano em primeira instância;

- o plano é submetido à aprovação da Assembléia Legislativa do Estado de São Paulo; e, finalmente,

- os comitês de bacias hidrográficas, baseados nas diretrizes aprovadas no plano estadual, definem prioridades regionais. 


\section{Quadro 3}

Composição do Conselho de Recursos Hídricos

\begin{tabular}{|c|c|}
\hline $\begin{array}{l}11 \text { secretários de Estado ou } \\
\text { representantes por eles } \\
\text { designados }\end{array}$ & $\begin{array}{l}\text { - Recursos Hídricos, Saneamento e Obras (presidente); } \\
\text { - Meio Ambiente (vice-presidente); } \\
\text { - Economia e Planejamento; } \\
\text { - Agricuitura e Abastecimento; } \\
\text { - Saúde; } \\
\text { - Transporte; } \\
\text { - Ciência, Tecnologia e Desenvolvimento Econômico; } \\
\text { - Esportes e Turismo; } \\
\text { - Fazenda; } \\
\text { - Administração e Modernização do Serviço Público. }\end{array}$ \\
\hline $\begin{array}{l}11 \text { prefeitos, representando os } \\
\text { seguintes grupos de bacias }\end{array}$ & $\begin{array}{l}\text { - } \text { Aguapeí/Peixe e Pontal do Paranapanema; } \\
\text { - } \text { Médio e Alto Paranapanema; } \\
\text { - } \text { Alto Tietê; } \\
\text { - Piracicaba/Capivari/Jundiaí; } \\
\text { - Sorocaba/Médio Tietê; } \\
\text { - Tietê/Jacaré, Tietê/Batalha e Baixo Tietê; } \\
\text { - Turvo/Grande e São José dos Dourados; } \\
\text { - Mogi-Guaçu, Pardo, Sapucaí/Grande e Baixo Pardo/Grande; } \\
\text { - Paraíba do Sul, Serra da Mantiqueira, Litoral Norte; } \\
\text { - Ribeira de Iguape e Litoral Sul; } \\
\text { - } \text { Baixada Santista. }\end{array}$ \\
\hline $\begin{array}{l}11 \text { representantes de usuários, } \\
\text { órgãos e entidades não- } \\
\text { governamentais }\end{array}$ & $\begin{array}{l}\text { - Federação das Indústrias do Estado de São Paulo (Fiesp); } \\
\text { - Federação da Agricultura do Estado de São Paulo (Faesp) e Associação } \\
\text { Brasileira de Irrigantes (Abrai) } \\
\text { - } \text { Associação dos Serviços Autônomos Municipais de Águas e Esgotos } \\
\text { (Assemae); } \\
\text { - Instituto de Engenharia de São Paulo; } \\
\text { - Associação Brasileira de Recursos Hídricos (ABRH), Associação } \\
\text { Brasileira de Águas Subterrâneas (Abas); } \\
\text { - Associação Brasileira de Irrigação e Drenagem (Abid), Associação } \\
\text { - } \text { Srasileira de Engenharia Sanitária e Ambiental (Abes); } \\
\text { - } \text { Conselho Regional de Engenharia, Arquitetura e Agronomia - (Crea); } \\
\text { - Sindicato dos Trabalhadores em Água, Esgoto e Meio Ambiente do } \\
\text { - Estado de São Paulo (Sintaema); } \\
\text { - } \text { Instituto dos Arquitetos do Brasil/São Paulo (IAB); } \\
\text { - Assembléia Permanente de Entidades de Meio Ambiente (Apedema). }\end{array}$ \\
\hline $\begin{array}{c}\text { PARTICIPAÇÃO ESPECIAL } \\
\text { Membros sem direito } \\
\text { a voz e voto. }\end{array}$ & $\begin{array}{l}\text { - Universidade de São Paulo (USP) } \\
\text { - Universidade Estadual Paulista (Unesp) } \\
\text { - Universidade de Campinas (Unicamp) } \\
\text { - } \text { presidério Público (MP) } \\
\text { - } \text { outros representantes de órgãos estaduais (sete) }\end{array}$ \\
\hline
\end{tabular}




\section{Fundo Estadual de Recursos Hídricos (Fehidro)}

O Fehidro é a instância que dá suporte financeiro ao Sistema Integrado de Gerenciamento de Recursos Hídricos, formado com recursos dos orçamentos dos governos do estado de São Paulo e dos municípios e também pela compensação financeira que a União paga ao estado pelo aproveitamento do potencial energético. Os empréstimos obtidos de instituições nacionais e internacionais podem integrar o fundo. Futuramente, também receberá os recursos arrecadados com a cobrança pelo uso dos recursos hídricos no estado. O seu comitê técnico é formado pelo Corhi, constituído pelos órgãos estaduais responsáveis pelos recursos hídricos nos aspectos quantitativos (DAEE e SRHSO) e qualitativo (Cetesb e SMA). O fundo é supervisionado por um conselho de oito membros, eleitos de forma paritária entre os representantes do estado e dos municípios que integram o Conselho Estadual de Recursos Hídricos. O fundo está estruturado em subcontas de forma que cada comitê de bacia pode gerenciar os seus próprios recursos. Essa é outra inovação importante e radical em termos de administração pública, pois, rompe com o secular princípio da unicidade do tesouro.

\section{Os comitês de bacias hidrográficas}

Os comitês de bacias hidrográficas são colegiados de decisão compostos por representantes do estado, dos municípios e de entidades da sociedade civil sediadas e com atuação comprovada na bacia hidrográfica. $\mathrm{O}$ número de membros de cada comitê é definido pelo seu plenário. Por isso, são observadas assimetrias entre os diferentes comitês. Bacias com um grande número de municípios e elevada densidade demográfica podem ter um número menor de membros do que um comitê de bacia com menor quantidade de municípios e menor densidade populacional. No Comitê da Baixada Santista foi verificado o menor número de votos por segmento (nove), enquanto no Comitê do Turvo/Grande verificou-se o maior (18 por segmento). No Comitê do Alto Tietê, onde estão representados os municípios da Grande São Paulo, são 16 votos por segmento. Qualquer que seja o número de membros, para determiná-lo deve ser observado o caráter paritário entre os três segmentos: estado, municípios e sociedade civil.

O plenário do comitê de bacia é a mais elevada instância política e decisória, exercendo funções estratégicas e deliberativas. É assessorado por uma secretaria-executiva e duas unidades descendentes, uma para a formação de comitês de sub-bacias e outra para a formação de grupos técnicos especializados. Com a aprovação da Lei Estadual $\mathrm{n}^{0}-10.020 / 98$, que autoriza a criação das agências de bacias hidrográficas, as atuais secretarias executivas deverão ser substituídas pelas agências. Os comitês de sub-bacias são formados quando um determinado corpo de água apresenta condições específicas que requerem tratamento especial, como poluição, assoreamento, enchentes etc. É o caso do Comitê do Alto Tietê, desmembrado em cinco subcomitês. A atuação dos grupos técnicos pode ser exemplificada com a elaboração do Projeto de Lei $\mathrm{n}^{\mathrm{o}}$ 20/1998, posteriormente substituído pelo Projeto de Lei $n^{\circ}$ 676/2000 que propõe a instituição de cobrança pelo uso de recursos hídricos. Foram formados dois grupos técnicos, sendo que um estudou e propôs os critérios para a cobrança, fazendo simulações nas diferentes bacias hidrográficas; enquanto o outro cuidou da redação do projeto de lei.

As secretarias executivas ou agências de bacias têm importância capital para os comitês de bacias. No âmbito da bacia hidrográfica são elas que gerenciam os 12 programas permanentes de uso, conservação e proteção dos recursos hídricos estabelecidos no plano estadual quadrienal. Esses são os programas:

- planejamento e gerenciamento dos recursos hídricos;

- aproveitamento múltiplo e controle dos recursos hídricos;

- serviços e obras de conservação, proteção e recuperação da qualidade dos recursos hídricos;

- controle da perfuração de poços profundos e da exploração das águas subterrâneas;

- conservação e proteção dos mananciais superficiais de abastecimento urbano;

- desenvolvimento racional da irrigação;

- conservação de recursos hídricos na indústria; 
- prevenção e defesa contra inundações;

- prevenção e defesa contra a erosão do solo e o assoreamento dos corpos de água;

- desenvolvimento dos municípios afetados por reservatórios e leis de proteção de mananciais;

- articulação interestadual e com a União;

- participação do setor privado.

Quando o Projeto de Lei n ${ }^{\circ}$ 676/00 for aprovado, as secretarias executivas e agências de bacias deverão propor mecanismos e valores de cobrança pelo uso de recursos hídricos na sua área de atuação, uma atribuição da Lei Federal $n^{\text {o }}$ 9.433/1997 (art. 38, inciso VI). No Conselho Estadual algumas funções são reservadas a determinados membros permanentes. A presidência é reservada à Secretaria de Recursos Hídricos e a vicepresidência à Secretaria de Meio Ambiente. Diferentemente, nos comitês de bacias não existem funções reservadas com exclusividade para nenhum segmento. Apesar dessa liberdade que permite aos representantes dos três segmentos assumirem qualquer função, existe uma tendência que se mantém na ampla maioria dos comitês. A presidência do comitê tem sido ocupada por um representante dos municípios, ou seja, por um prefeito. A vice-presidência tem sido ocupada por um representante da sociedade civil e a secretaria-executiva, por um representante do estado, principalmente do DAEE.

Esse critério foi estabelecido como um modelo desde a criação do Comitê da Bacia Hidrográfica dos Rios Piracicaba, Capivari e Jundiaí, o primeiro a ser instalado em São Paulo. A composição adotada na eleição desse primeiro comitê procurou estabelecer equidade de espaços para a participação dos três segmentos no colegiado de gestão. Os prefeitos representantes dos municípios que integram a bacia indicaram o presidente do colegiado, demarcando o caráter descentralizador da política estadual de recursos hídricos. Aos representantes das entidades da sociedade civil coube a indicação do vice-presidente do colegiado, sinalizando participação democrática e transparência nas ações. Já os representantes do poder público estadual indicaram o secretário executivo do colegiado, por tratar-se da instância política e administrativa detentora de mais informações e maior capacidade para a mobilização de recursos humanos, materiais e financeiros. Conforme Neder (2002), não é pacífico esse critério de divisão de cargos entre segmentos, conhecido como o "critério PCJ". Mesmo assim, esse critério foi seguido pela maioria dos outros comitês de bacias, embora a sua aplicação seja de caráter voluntário (p.191).

O critério PCJ e a composição dos colegiados de gestão dos comitês de bacias são alvos de diversos questionamentos críticos. O critério PCJ seria uma manobra sutil dos representantes do estado. Conforme depoimento de um membro do Comitê do Alto Tietê concedido a Neder (2002), é uma preocupação dos representantes do estado garantir politicamente os cargos para cada uma das três partes com assento no colegiado, implicando riscos de se colocar as disputas por cargos acima das discussões sobre políticas e estratégias de ação. Membros do Comitê do Alto Tietê entrevistados por Neder (2002) revelaram preferir que houvesse a formação de chapas em vez de disputas individuais para preenchimento dos cargos de presidente, vice e secretário.

Ainda quanto aos comitês de bacias, há diversos questionamentos no que diz respeito não somente à sua composição, mas também em relação à eficiência e legitimidade. Quanto à composição, a principal questão que se levanta diz respeito ao caráter tripartite. Os críticos consideram que estado e municípios são, em essência, poder público governamental e que, assim, o setor público estaria super-representado em detrimento da sociedade civil, que estaria sub-representada. Esse argumento pode estar condicionado por uma visão dicotômica do tipo nós e eles, que;

- enxerga as relações entre os entes públicos (estado e poder local) como necessariamente harmônicas e

- as relações entre estes e a sociedade civil como antagônicas.

Por esse motivo o modelo adotado em Minas Gerais aparece como contraponto ao de São Paulo, na visão dos críticos do modelo paulista. Em Minas Gerais, o sistema procurou contemplar a paridade entre o poder público 
e a sociedade civil. Cada um desses dois segmentos detém 50\% dos membros representantes nos comitês. Por sua vez, o sistema paulista se fundamentou no entendimento de que:

- os interesses dos três segmentos representados no colegiado não são necessariamente nem harmônicos, nem conflitantes;

- o poder estadual e o poder local nem sempre pensam as mesmas coisas sobre os problemas ambientais, em especial sobre as questões relacionadas ao uso de recursos hídricos; e

- o caráter tripartite abriria espaço para se apreciar um mesmo problema sob diferentes pontos de vista, além de estimular uma discussão baseada em conflitos moderados, estimulando a construção de acordos móveis e provisórios, estabelecendo processos criativos de negociações e composições e evitando o maniqueísmo e a dicotomização política. Desse modo, a forma e a abrangência da atuação de cada segmento representado no comitê foram considerados mais importantes do que seu caráter público ou privado.

No estado de São Paulo, a busca de soluções para os conflitos internos nos comitês de bacias hidrográficas está fundamentada numa estratégia de longo prazo. Essa estratégia apresenta resultados que podem ser considerados positivos em vários aspectos, principalmente, por instituir um sistema regulador multidimensional, envolvendo critérios de utilidade pública, de mercado, social e de sustentabilidade ambiental. Embora limitações possam ser apontadas no funcionamento do sistema e na efetiva participação da sociedade civil, ele ampliou o escopo das decisões sobre recursos hídricos, ao adotar, com pesos semelhantes, dimensões antes esquecidas ou subordinadas ao interesse econômico, quer do Estado ou das grandes empresas de algum modo vinculadas ao setor energético.

Essa linha de pensamento está baseada no fato de que o estado detém uma visão macro dos processos relativos aos recursos hídricos; os municípios, uma visão circunscrita aos interesses locais e regionais; e as entidades da sociedade civil, uma visão pulverizada e fragmentada, por vezes, representando interesses e necessidades específicos. De certo modo, o histórico da atuação dos comitês mostra acerto nessa estratégia. Os representantes da sociedade civil agem a partir de acordos - ora com o poder local, ora, e principalmente, com o poder estadual -, sem estabelecerem alinhamentos automáticos. Um exemplo recente ocorreu na reunião de 10 de dezembro de 2003, do comitê do Piracicaba, realizada na cidade de Extrema (MG), quando as entidades da sociedade civil se juntaram aos municípios para derrotar a proposta do estado de reter $25 \%$ dos recursos obtidos com a cobrança pelo uso da água, para promover uma redistribuição entre as bacias com menor possibilidade de arrecadação. Aliás, o resultado da votação nesse comitê, foi exceção à regra, uma vez que os demais comitês aprovaram a proposta do estado, a qual, contudo, não deverá ser implementada por falta de consenso.

A eficiência dos comitês é questionada pelas pessoas de fora do sistema e pelas que se opõem a ele. As críticas têm adotado um viés "produtivista", como se os comitês fossem empresas privadas. Geralmente, tomam como referência as bacias onde os problemas e os conflitos envolvendo o uso de recursos hídricos são inexistentes ou de menor dimensão. Nessas bacias, não é raro que, com exceção das reuniões que ocorrem em torno de uma pauta mais ampla, os encontros dos membros do comitê adquiram um tom menos formal, encaminhando-se para um espaço de convivência social. Entretanto, é preciso deixar claro que esse não é o clima que marca as reuniões dos comitês de bacias nas quais o uso dos recursos hídricos está próximo da saturação e a sua degradação em estágio acelerado. Nesses comitês - caso do Alto Tietê, Baixada Santista, Mogi e Piracicaba -, as controvérsias, as disputas e os conflitos quase sempre elevam a temperatura das discussões, ultrapassando os polidos tons político e diplomático. Seguramente, esse clima de discussão e conflito é a regra e não a exceção, na maioria dos comitês de bacias de São Paulo. Como se sabe, para decisões tomadas por grupos com autonomia não se pode esperar agilidade ou eficiência, como ocorreria nas empresas. Porém, as decisões desses comitês costumam ser mais eficazes, por levaram em conta diferentes pontos de vistas e por considerarem os interesses das diversas partes envolvidas. Nesse sentido, qualquer medida dos comitês deve considerar esses aspectos, por serem inerentes ao processo de construção coletiva a que se propõem.

Alguns críticos (também situados fora do sistema) vêem falta de legitimidade política nos colegiados, porque seus membros não foram escolhidos em processo eleitoral. De fato, os colegiados que dirigem os comitês 
podem assumir diferentes papéis, inclusive o de instância política decisória. Considerando a experiência do Comitê do Alto Tietê, Neder (2002), identifica duas linhas centrais na atuação dos comitês: uma, como instância de coordenação técnica, e outra, como colegiado máximo de decisão. Nessa segunda linha de atuação, as decisões do colegiado são desdobradas para subcomitês que devem implementá-las. Por não terem capacidade "governativa", esses comitês têm que buscar a construção, ad hoc, de uma base de representatividade entre os poderes Executivo e Legislativo. Especialmente entre os membros do poder local, são constatadas certas resistências para aceitar a co-responsabilidade dos comitês e subcomitês de bacias, uma vez que determinados dirigentes locais não reconhecem a sua legitimidade e representatividade. Contudo, é conveniente lembrar que desde a década de 1930 até muito recentemente, as políticas de uso dos recursos hídricos eram definidas, fundamentalmente, pelo setor de geração de energia elétrica, com alguma participação do setor de saneamento básico, o qual também não tinha legitimidade ou representatividade política.

Finalmente, a capacitação dos técnicos que atuam nos comitês e a falta de estrutura das entidades que representam a sociedade civil são desafios importantes a serem enfrentados. A transferência de conhecimentos vem sendo estimulada, mas isso é um processo lento, principalmente pela complexidade envolvida na questão dos recursos hídricos, em face da amplitude de outros temas e interesses agregados. Quanto às entidades civis, por vezes seus representantes não dispõem de condições mínimas para acompanhar as discussões e as reuniões dos comitês. Alem disso, verifica-se que algumas entidades civis ainda não dispõem de estrutura física mínima apropriada e, não raramente, de recurso financeiro para cobrir as despesas dos seus representantes.

\section{Considerações finais}

A forma como está estruturado o Sistema Integrado de Gerenciamento de Recursos Hídricos no Estado de São Paulo aponta para uma nova perspectiva nas relações do Estado com a sociedade, uma perspectiva de democratização e de participação responsável. Isso não passa despercebido para alguns poucos técnicos e políticos conservadores, que vêem no sistema uma ação política estratégica intencional para se reduzir o poder do Estado e da autoridade política legalmente constituída. Faltariam a esses colegiados de gestão, formados pelos comitês de bacias hidrográficas e pelo Conselho de Recursos Hídricos, a legitimidade delegada pela sociedade nos processos eleitorais. Contudo, os planos aprovados por esses colegiados são submetidos à aprovação da autoridade legislativa estadual. Muitas decisões tomadas atualmente pelos colegiados, tanto no plano central como descentralizado, eram tomadas por burocratas que também não possuíam legitimidade política.

Dessa forma, o poder público está diante de um desafio que não lhe permite ficar preso aos modelos formais de democracia. É preciso buscar a democratização das estruturas públicas, fazendo com que reflitam melhor as manifestações de solidariedade e, também, as contradições da sociedade brasileira. Provavelmente, uma boa maneira para se fazer isso é pela busca permanente do controle social das organizações públicas. Como todo processo democrático, a implantação do SIGRH e, particularmente, dos comitês de bacias, tem sido barulhenta, tumultuada e, principalmente, conflitante. Contudo, não se encontrou quem propusesse a reversão do sistema. Mesmo os grupos divergentes concordam que ele tem sido, sobretudo, um processo de aprendizado para todos os envolvidos.

A descentralização do poder de decisão - combinada com a centralização de diretrizes e a democratização dos órgãos desse sistema - pode significar um marco nas experiências de institucionalização da participação da sociedade na formulação, implantação e avaliação de políticas públicas no Brasil. Um sistema com essa complexidade, sem uma diretriz central, poderia se tornar inócuo, não apresentar resultados ou perder o seu caráter sistêmico. Sem a descentralização, as decisões e ações poderiam se perder na irracionalidade administrativa. Sem a democratização, transferindo o poder das estruturas estatais para um novo espaço público compartilhado, com novos significados, a legitimidade das decisões poderia se perder na falta de transparência.

O sistema estadual permite combinar com eficiência instrumentos de política pública do tipo comando e controle - como é caso da outorga para poder usar a água - com instrumentos econômicos, como a cobrança pelo seu uso. O sistema se mostra eficiente, sobretudo, na sua estratégia de convergir para um mesmo espaço 
decisório diversos órgãos públicos, usuários de água e sociedade civil, muitas vezes, com interesses contraditórios, fazendo com que os interesses de cada setor e os custos sociais inerentes sejam abertamente discutidos. Assim, os interesses de uns e outros se regulam mutuamente, sinalizando para uma possibilidade de equacionar problemas de agência envolvendo as relações do Estado com a sociedade.

Quanto aos problemas relacionados à escassez de água, estes já se mostram preocupantes. A água é o elo entre tudo que tem vida, conectando passado, presente e futuro. Nesse sentido, as gerações atuais também têm responsabilidades com as futuras gerações, às quais se deve legar condições de suprir suas necessidades de recursos naturais, principalmente de água. Portanto, parece haver razoável consenso, em escala planetária, sobre a necessidade de se reverter o atual quadro de degradação, adotando-se uma visão coletivista de propriedade e uma ética de compromisso e cuidado com a água. A comunidade científica já dispõe de considerável volume de conhecimentos sobre todo o ciclo hidrológico e os processos de degradação da água. Contudo, o impacto das ações humanas sobre a sua disponibilidade e circulação ainda é a grande interrogação que estudos específicos precisarão responder com alguma urgência. Como afirma Tundisi (2003, p.206),

“a solução para os problemas da água está, por um lado, nos avanços tecnológicos necessários (soluções científicas e de engenharia) e, por outro, nos avanços políticos, gerenciais e de organização institucional em nível de bacias hidrográficas, consórcios de municípios, bacias interestaduais e internacionais."

O atual sistema paulista representa uma importante - ainda que parcial - solução do problema, pois significa avanço considerável em termos políticos e de gestão. A experiência ainda é recente, mas o avanço se revela, sobretudo, pela capacidade de manter distância de modismos, seja da influência neoliberal - que apregoa uma espécie de fundamentalismo de mercado -, seja da natureza estatizante e autoritária que se vale das agruras da democracia para afirmar maior eficiência. É provável que em se tratando de política ambiental - e mais especificamente de recursos hídricos, um recurso único para o qual não existem substitutos -, tanto o Estado quanto o mercado, isoladamente, não sejam soluções. Sabidamente, nem a burocracia pública e, menos ainda, o mercado têm entre os seus princípios de atuação a solidariedade. Quase sempre a frenética busca de competitividade corporativa entra em conflito com os paradigmas do desenvolvimento sustentável, definido como a capacidade das gerações atuais satisfazerem suas necessidades sem, contudo, comprometerem a possibilidade das gerações futuras satisfazerem as suas. São inúmeros os fracassos do poder público na condução de políticas sociais e ambientais. Em muitos casos, isso tem feito - inclusive no Brasil dos últimos tempos -, com que o Estado abra mão do seu papel, transferindo-o para grandes corporações globais. Porém, experiências de execução de políticas de interesse social pela iniciativa privada ainda carecem de melhor análise crítica. Em alguns países da Europa, onde o gerenciamento dos recursos hídricos foi completamente privatizado, o preço da água subiu de forma brutal e linear. Portanto, o gerenciamento da água deve levar em conta que esta é um fator de inclusão social e que por se tratar de um bem limitado, não deve conduzir ao reducionismo econômico, desprezando a vida coletiva.

Hoje, as grandes companhias internacionais, por vezes lutam e por vezes cooperam entre si, na busca pelo controle da informação, do dinheiro e da água. Desenvolvem o que no mundo dos negócios é denominado de "consumidorização". Assim, não oferecerão aos seus consumidores apenas água, mas água segmentada: para grávidas, para crianças, para velhos, para esportistas etc. No limite, implementarão estratégias de comercialização que terão como objetivo principal a maximização da riqueza dos acionistas, procurando fornecer sempre mais para alguns em vez de algum para todos. É de se perguntar se é válido aumentar a riqueza do mundo, elevando o valor das ações de algumas megacorporações globais, concentrando essa riqueza nas mãos de uns poucos, ao passo que uma parcela cada vez maior da população é excluída e só conhece a pobreza. É preciso cuidar para que a água, até recentemente considerada propriedade de ninguém, não transite, no extremo oposto, para uma propriedade de poucos. Como ensinou Aristóteles há mais de 2.500 anos, os vícios estão nos extremos. E, em se tratando de recursos hídricos, Estado e mercado, tomados isoladamente, são pólos extremos de um mesmo jogo que procura excluir iniciativas mais amplas de participação social. 


\section{Referências bibliográficas}

BRASIL. Constituição (1988). Constituição da República Federativa do Brasil. Brasília, DF: Imprensa Nacional, $1997 a$.

. Lei n- 9.433, de 8 de janeiro de 1997. Institui a Política Nacional de Recursos Hídricos, cria o Sistema Nacional de Gerenciamento de Recursos Hídricos... Lex, São Paulo, 1997b.

. Lei no 9.984, de 17 de julho de 2000. Dispõe sobre a criação da Agência Nacional de Águas - ANA. Lex, São Paulo, 2000.

CONAMA. Resolução nำ 20 de 18de junho de 1986. Dispõe sobre a classificação das águas doces, salobras e salinas do território nacional. Diário Oficial [da] República Federativa do Brasil, Brasília, DF, 30 jul. 1986.

GARRIDO, R. Considerações sobre a formação de preços para a cobrança pelo uso da água no Brasil. In: Thame, A. C. M. (Org.). A cobrança pelo uso da água. São Paulo: Igual, 2000. p.57-91.

INSTITUTO BRASILEIRO DE GEOGRAFIA E ESTATíSTICA. Censo Demográfico 2000. Rio de Janeiro: IBGE, 2000.

NEDER, R. T. Crise socioambiental. Estado \& sociedade civil no Brasil (1982-98). São Paulo: Annablume/Fapesp, 2002.

NOVAES, W. (Coord.). Agenda 21 brasileira - bases para discussão. Brasília: M M A/PNUD, 2000.

PETRELLA, R. 0 manifesto da água - argumentos para um contrato mundial. Petrópolis: Vozes, 2002.

REBOUÇAS, A. C. Estratégias para se beber água limpa. In: 0 município no século XXI: cenários e perspectivas. São Paulo: FPFL/Cepam, 1999. p.199-215.

Água doce no mundo e no Brasil. In: REBOUÇAS, A. C.; BRAGA, B.; TUNDISI, J. G. Águas doces no Brasil - capital ecológico, uso e conservação. 2 ed. São Paulo: Escrituras Editora, 2002.

SÃO PAULO. Lei no 6.134, de 2 de junho de 1988. Dispõe sobre a preservação dos depósitos naturais de águas subterrâneas do estado de São Paulo. Lex, São Paulo, 1988.

Decreto n- 32.954 de 7 de fevereiro de 1991. Dispõe sobre a aprovação do 1 ํ Plano Estadual de Recursos Hídricos - PERH 1990/91. Lex, São Paulo, 1991a.

. Lei n- 7.663, de 30 de dezembro de 1991. Estabelece normas de orientação à Política Estadual de Recursos Hídricos, bem como ao Sistema Integrado de Gerenciamento de Recursos Hídricos. Lex, São Paulo, 1991b.

$\overline{1} \overline{9} \overline{3} \bar{a}$.

Decreto no 37.300, de 25 de agosto de 1993. Regulamenta o Fundo Estadual de Recursos Hídricos - Fehidro. Lex, São Paulo, $\overline{1} \overline{9} \overline{9} \bar{b} \bar{b}$.

Lei no 8.275, de 29 de março de 1993. Cria a Secretaria de Estado de Recursos Hídricos, Saneamento e Obras. Lex, São Paulo,

. Lei no 9.034, de 27 de setembro de 1994. Dispõe sobre o Plano Estadual de Recursos Hídricos - PERH. Lex, São Paulo, 1994.

Constituição do Estado de São Paulo, de 05 de outubro de 1989. São Paulo: Imprensa Oficial do Estado, 1997.

Lei $n^{\circ}$ 10.020, de 3 de julho de 1998. Autoriza o Poder Executivo a participar da constituição de fundações agências de bacias hidrográficas dirigidas aos corpos de águas superficiais e subterrâneas de domínio do estado de São Paulo. Lex, São Paulo, 1998.

Projeto de Lei n- 676, de 11 de dezembro de 2000. Dispõe sobre a cobrança pela utilização de recursos hídricos do domínio do Estado de São Paulo. Diário Oficial, São Paulo, 12 dez. 2000.

SENRA, João Bosco. Água, o desafio do terceiro milênio. In: VIANA, Gilney; SILVA, Marina; DINIZ, Nilo (Organizadores). 0 Desafio da Sustentabilidade - um debate socioambiental do Brasil. São Paulo: Fundação Perseu Abramo, 2001. p.133-144.

THAME, Antônio Carlos Mendes. Fundamentos e antecedentes. In: THAME, A. C. M. (Org.). A cobrança pelo uso da água. São Paulo: Igual, 2000. p.11-16.

TUNDISI, José Carlos Galizia. Água no século XXI - enfrentando a escassez. São Carlos: RiMa, IIE, 2003.

UNIÃO INTERNACIONAL PARA A CONSERVAÇÃO DA NATUREZA (UICN); Programa das Nações Unidas para o Meio Ambiente - PNUMA; Fundo Mundial para a Natureza - WWF. Cuidando do planeta Terra - uma estratégia para o futuro da vida. São Paulo: UICN/Pnuma/WWF, 1991. 